\title{
Nothing in biology begins when you think it does
}

\author{
Review of Shubin, N. 2020. Some Assembly Required: Decoding Four Billion Years of \\ Life, from Ancient Fossils to DNA. Pantheon Books, New York
}

Norman Johnson ${ }^{*}$

\begin{abstract}
Neil Shubin has written an excellent, accessible book explaining how innovations in biology evolve. The key insightone provided by Darwin but fleshed out by biologists over the subsequent century and a half-is that the precursors of traits involved in innovations usually were present in the ancestors but had a different function. In this book, Shubin also provides rich biographical detail of the scientists involved in the discoveries.
\end{abstract}

Most semesters I teach "Writing in Biology" to undergraduates, mostly of which are juniors and seniors. Among the assignments is a review of a non-fiction book in biology from the last ten years. In the process of teaching the class multiple times, I have cultivated a list of recommended books. Although I allow students the freedom to choose books not on the list (with my approval), most choose one from the list. One of my aims for assigning a book review and cultivating this list is to motivate students to read more long-form works in their major. We are blessed with an abundance of excellent bookssome by scientists, others by science journalists and writers-in so many areas of biology from genetics to paleontology to medicine, among others. If they are not reading at least some of these works, students are missing out on a vital part of their education.

A perennial favorite on my list has been Neil Shubin's (2008) Your Inner Fish. In this relatively short work, Shubin traced the steps taken to find Tiktaalik, a fossil that has transitional features between a fish-like existence and an amphibian one. Shubin displayed how the process of science works while discussing both the paleontological and the genetic work that led to the discovery of

${ }^{*}$ Correspondence: njohnson@ent.umass.edu

Department of Biology, University of Massachusetts, Amherst 01003, USA
Tiktaalik. In addition, Shubin discussed the ramifications of the fact that we evolved from a fish.

But time marches on. Your Inner Fish is now a dozen years old and is no longer on my cultivated list. While that may not seem like such a long time to a fifty-something instructor-I have mugs that are twice as old-it is more than half the age of a traditional college student who was in elementary school when Your Inner Fish came out. Moreover, many fields in biology-including genomics-have substantially advanced since 2008. Our ability to sequence genomes has drastically improved. We can easily edit genes with CRISPR something that was not even on the horizon in 2008. The good news is that Neil Shubin now has a new, excellent book-Some Assembly Required - that will go on my list.

The premise of Shubin's new book is the same as the challenge Darwin received from one of his critics, the iconoclastic St. George Mivart. A generation younger than Darwin, Mivart was working on comparative anatomy as an apprentice to Thomas Huxley when Darwin published The Origin of Species. Although, Mivart initially accepted Darwin's theories of evolution, he grew more doubtful as the years went on. What bothered Mivart was the origin of the initial stages of an adaptive feature. The challenge he posed to Darwin was what good is a small part of a wing or any other feature? In other

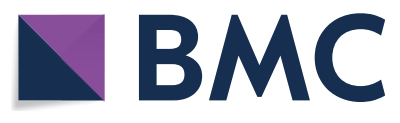

(c) The Author(s) 2020. This article is licensed under a Creative Commons Attribution 4.0 International License, which permits use, sharing, adaptation, distribution and reproduction in any medium or format, as long as you give appropriate credit to the original author(s) and the source, provide a link to the Creative Commons licence, and indicate if changes were made. The images or other third party material in this article are included in the article's Creative Commons licence, unless indicated otherwise in a credit line to the material. If material is not included in the article's Creative Commons licence and your intended use is not permitted by statutory regulation or exceeds the permitted use, you will need to obtain permission directly from the copyright holder. To view a copy of this licence, visit http://creativeco mmons.org/licenses/by/4.0/. The Creative Commons Public Domain Dedication waiver (http://creativecommons.org/publicdomain/ zero/1.0/) applies to the data made available in this article, unless otherwise stated in a credit line to the data. 
words, why would the nascent structures provide any benefit in terms of survival or reproduction?

Darwin responded in the sixth edition of The Origin of Species that characters change gradually, "often accompanied by a change of function", a phrase that Shubin highlights (p. 14). The key insight is that the function that the nascent characters provide often is distinct from the function they provide the organism when fully formed. Shubin provides several examples of this gradual change with change of function beginning with lungs in fish and feathers in the ancestors of birds. Lungfish, Shubin notes, have lungs in addition to gills. Shubin follows: "Lungs aren't some invention that abruptly came about as creatures evolved to walk. Fish were breathing air with lungs well before animals ever stepped onto terra firma." (p. 20). Extending this message, Shubin states "biological innovations never come about during the great transition they are associated with. Feathers did not arise during the evolution of flight, nor did lungs and limbs originate during the transition to land. What's more, these great revolutions in the history of life, and others like them, could never have happened otherwise. Major changes in the history of life didn't have to wait for the simultaneous origin of many inventions. Innovations have antecedents that extend deep in time" (p. 30).

One extension of this thesis, which Shubin did not fully fleshed out, is that the seeds of future innovations are here now. Given a fortuitous set of circumstances, these seeds can lead innovations presently not existing. Figuring out which innovations are likely to evolve is challenging because the circumstances leading to such innovations are at least partially contingent.

Shubin focuses on the innovations that occur on the inside of the organism - those affecting the morphology and physiology. The principle also holds for ecological changes as well. For instance, consider the evolution of pollinating bees, which originated as a lineage of predatory wasps. How do organisms go from hunting prey to eating and transferring the pollen of plants? The recent finding that bees are most closely related to wasps that hunt thrips, small insects that pollinate flowers, makes this transition less mysterious. An intriguing hypothesis is that the nascent bees went from hunting pollinators to being predators themselves (Danforth et al. 2019). Assuming that the hypothesis is correct, being attracted to flowers was an important antecedent to the transition to pollination. As Shubin argues. "Innovations have antecedents that extend deep in time. Nothing ever begins when you think it does." (p.30)

Reading Shubin's prose, I am reminded of the thrill I had reading Stephen Jay Gould's essays with their erudition, historical insight, and colorful turns of phrase. Shubin was a graduate student at Harvard during the 1980s where he was a teaching assistant for Gould. He recalls Gould asking his paleontology class "what if" questions such as what would life be like if the asteroid that killed the non-avian dinosaurs had missed? How would mammals have evolved had these large dinosaurs survived? Not long after, Gould would flesh out the argument that life would be strikingly different had small changes happened due to inherent contingencies in his book Wonderful Life. In the three decades since Gould's (1990) book, biologists are better able to systematically test the importance of contingency versus determinism in evolution. Shubin highlights work by Jonathan Losos on Anolis lizards in Caribbean islands where evolution on each island can serve as a natural experiment. Losos, who recently expanded on the contingency- determinism debate in his own book (Losos 2017), has found that lizards on each island have repeatedly and independently evolved similar modes of living. Shubin notes: "These natural experiments reveal that the history of life is not wholly a crapshoot of contingent events. The dice are loaded by the ways genes and development build bodies, by the physical constraints of environments, and by history." (p. 173). The loading of these dice channels evolution in particular and to some extent predictable directions.

One of the most appealing features of Shubin's book is his recounting of rich, biographical detail of the scientists-many who are from underrepresented groups and many who have not received much prior attention. One key figure is Julia Barlow Platt (1857-1943) who used classic embryology techniques to show that cells can migrate during development. In particular, the cells from the nascent spinal cord can migrate to make new tissues all over the body from gill bones to pigment cells to the myelin that insulate nerve cells. These observations illustrate that the functions of cell types can change via evolution. Despite the importance of her studies, Platt-like most women of the era-encountered much difficulty in securing an academic position. So, she eventually turned to politics and became the mayor of Pacific Grove, California. As mayor, she led a campaign to provide a sanctuary to protect Monterrey Bay.

Just after the release of Some Assembly Required, Emmanuelle Charpentier and Jennifer Doudna won the 2020 Nobel Prize in Chemistry for their work on developing CRISPR/Cas9 genome editing, one of the most important technologies in biomedical research. With CRISPR editing, scientists across the world are altering genomes of all sorts of organisms. Shubin concludes Some Assembly Required noting that the CRISPR system had evolved in bacteria as a defense against viruses. $\mathrm{He}$ waxes philosophic: "There is something subline to the notion that our conscious brain had achieved what cells and genomes have been doing on their own for billions 
of years. A technology invented in one creature, bacteria, has been taken, modified, and co-opted to change others." (p. 191). I hope my future students get a chance to contemplate that.

\section{Acknowledgements}

None.

\section{Authors' contributions}

NAJ is the sole author of the article. The author read and approved the final manuscript.

\section{Funding}

None.

Availability of data and materials

Not applicable.

Ethics approval and consent to participate

Not applicable.

\section{Consent for publication}

Not applicable.

\section{Competing interests}

Not applicable.

Received: 25 November 2020 Accepted: 27 November 2020

Published online: 04 December 2020

\section{References}

Danforth BN, Minckley RL, Neff JL. The solitary bees: biology, conservation, ecology. Princeton: Princeton University Press; 2019.

Gould SJ. Wonderful life: the burgess shale and the nature of history. New York: W. W. Norton and Company; 1990

Losos JB. Improbable destinies: fate, chance, and the future of evolution. New York: Riverhead Books; 2017

\section{Publisher's Note}

Springer Nature remains neutral with regard to jurisdictional claims in published maps and institutional affiliations.
Ready to submit your research? Choose BMC and benefit from:

- fast, convenient online submission

- thorough peer review by experienced researchers in your field

- rapid publication on acceptance

- support for research data, including large and complex data types

- gold Open Access which fosters wider collaboration and increased citations

- maximum visibility for your research: over 100M website views per year

At $\mathrm{BMC}$, research is always in progress.

Learn more biomedcentral.com/submissions 